\title{
Analysis of the factors affecting the effectiveness of character- based intructional video implementation to early childhood education in padang
}

\author{
Abna Hidayati ${ }^{1}$, Alwen Bentri ${ }^{2}$, Dedi Supendra ${ }^{3}$ \\ ${ }^{123}$ Universitas Negeri Padang
}

\section{Article Info}

Article history:

Received Nov $3^{\text {rd }}, 2018$

Revised Nov $7^{\text {th }}, 2018$

Accepted Nov 13 ${ }^{\text {th }}, 2018$

\section{Keyword:}

Instructional Video

Character Values

Learning Strategies

\begin{abstract}
The education of character to the early childhood is essentially important because this stage is the golden stage to construct the child's characters. However, the implementation of character education with instructional media encounters crucial problems especially applying the educational video. This study is to identify the factors which are influencing the effectiveness of character-based instructional video implementation to the early childhood education in Padang. This research conducts the quantitative approach with quasi-experiment. In addition, it involves 125 early childhood students in PAUD Adzkia II Tabing, Koto Tangah, Padang. Specifically, this study applies the purposive sampling categorised to Class A and Class B with 17 students in each. Both classes then were given discrete treatments to observe the ability of character education. The data was collected with questionnaires. The results concluded that there is significant distinction between the students who are treated with video and those who are only with uncomplicated pictures. Therefore, it is suggested that character-based educational video media is able to be implemented to increase the mastery of characters' values to the early childhood students with supporting learning strategies.
\end{abstract}

C 2018 The Authors. Published by Redwhitepress.

This is an open access article under the CC BY-NC-SA license

(https://creativecommons.org/licenses/by-nc-sa/4.0/

\section{Corresponding Author:}

Abna Hidayati

Universitas Negeri Padang

Email: abnahidayati@pps.unp.ac.id

\section{Introduction}

Mastery of character values is one of the important goals of education in early childhood (Wang, J et al, 2015). In the curriculum applied in early childhood and elementary school in Indonesia, the character becomes an important concern. It is also supported by the formulation of the National Education System Act of 2003 which states that one of the education urgencies is to inculcate the character values. Education assuredly starts from the early education level that is early childhood. As it is known, the period of early age is a golden moment where it will be quite relatively effortless to form their character, behaviour and mental. Character values in early childhood are obtained by the child through imitation activities. Children will be very easy to imitate the behavior of the people around them and what they watched (Koesoema, 2007).

Learning video is one of alternative media which appeals to children. Learning methods for early childhood students that are appropriate for their cognitive development are by telling stories and listening to videos. Storytelling can be done by using the images or hand puppets (Liang, H, 2015). Furthermore, using video can be applied by optimizing viewing images and animations and living characters. The video is an alternative media, which is attractive to children because it contains animated elements and moving 
images that stimulate children interested in learning. The use of video in teaching character aids to visualize the character's value in children (Hidayati, 2015). This study aims to determine the factors that influence the mastery of character values by using video comparing it with the images.

\section{Method}

The type of research is quantitative with experiment using pretest and post-test design with group control design. The study was conducted at Yayasan Pendidikan Adzkia, with class A and B groups. Samples were part of the population to be taken using a particular method applied as research subjects. Sampling is the process of selecting portions of the population that can represent the existing population. The sampling technique in this research is the total sampling where all the population members are used as the research samples. The samples in this study are divided into two classes namely class A and B with 17 students per class.

\section{Results and Discussions}

The study about the influencing factors of the character-based instructional video implementation for early childhood students was conducted with the experimental method to two classes, such as:

1. Class A using an instructional video which comprises the information of character-based educational video to the early childhood students. The learning process was happened by means of students collected in class. Furthermore, the teacher gave the orientation and information and after that, the teacher and students watched the character education video. After watching the video, the teacher and the students discussed the implementation of the character values contained in the video.

2. Class B by using pictorial story media. The teacher gave an explanation in front of the students by showing the storybook equipped with the media images. After the lesson held, discussion about the character values was conducted between teachers and students.

Meanwhile, for a sample group with instructional video, the researchers apply the discussion and telling stories with students about the provided materials which had been uploaded to the video. For example, to implement the character of independent, the research put an illustration in the video about a child who was managing his shoes and his bag neatly when he had just arrived at schools. After watching the video, the teacher had a discussion with the students about the positive attitude showed by a good child in the video when he had just come at schools. Furthermore, it was conducted the trial to implement the character value performed in the video by the students and then the collected data was analysed with SPSS. The analysis output can be seen in the table below:

1. The difference on average score of character value's mastery between the class with simple image and instructional video.

\begin{tabular}{lllccccc}
\hline Category & & N & Mean & SD & Min-Maks & Lower & Upper \\
\hline \multirow{2}{*}{ Video } & Pretest & 17 & 11.70 & 3.122 & $7-16$ & 10.05 & 13.53 \\
Story & Post Test & & 13.73 & 2.728 & $9-17$ & 13.23 & 16.23 \\
telling & Pretest & 17 & 11.50 & 4.889 & $1-16$ & 8.89 & 14.89 \\
& Post Test & & 12.67 & 3.255 & $8-17$ & 13.02 & 16.88 \\
\hline
\end{tabular}

According to the data above, it is found that there was the distinction of average score between the before and the after trial to the video sample group. Initially, the average value of this category is 11.70 . Then, the average score increased to 13.73 after being treated with the video. Meanwhile, it is also can be noted that the increase point also is experienced by the sample group with simple images. The average score after the trial is 12,67 , higher than the average score before the students was given the uncomplicated pictures.

2. The difference on the average score of the value of students' character mastery between video and simple image sample group. 


\begin{tabular}{|c|c|c|c|c|c|c|c|c|c|}
\hline & & \multicolumn{8}{|c|}{ Paired Samples Test } \\
\hline & & \multicolumn{5}{|c|}{ Paired Differences } & $\mathrm{t}$ & $\mathrm{df}$ & Sig. \\
\hline & & \multirow{4}{*}{$\begin{array}{l}\mathrm{Me} \\
\text { an }\end{array}$} & \multirow{4}{*}{$\begin{array}{l}\text { Std. } \\
\text { Deviati } \\
\text { on }\end{array}$} & \multirow{4}{*}{$\begin{array}{l}\text { Std. } \\
\text { Error } \\
\text { Mean }\end{array}$} & \multirow{3}{*}{\multicolumn{2}{|c|}{$\begin{array}{c}95 \% \text { Confidence } \\
\text { Interval of the } \\
\text { Difference }\end{array}$}} & & & $(2-$ \\
\hline & & & & & & & & & taile \\
\hline & & & & & & & & & d) \\
\hline & & & & & Lower & Upper & & & \\
\hline Pair & strategy & - & 2.173 & 3.846 & -5.8534 & - & - & 16 & 0.00 \\
\hline \multirow[t]{2}{*}{1} & - video & 2.92 & & 58 & & 3,7358 & 5,11 & & 4 \\
\hline & & 2 & & & & 4 & 2 & & \\
\hline Pair & Sta1 - & 3.20 & 3.173 & 2.754 & - & - & - & 16 & 0.00 \\
\hline \multirow[t]{2}{*}{2} & vid1 & 8 & & 74 & 4.5411 & 2,6588 & 3,40 & & 1 \\
\hline & & & & & 6 & 1 & 3 & & \\
\hline
\end{tabular}

The table above indicated that the average knowledge before and after given an intervention through video media about the understanding of character values is -2.922 (showed the result before the treatment was lesser than after the treatment) with standard deviation 2.173. Furthermore, at the trial with video, it is obtained the average score around 3.208 with standard deviation 3.172 and alfa about 0.001 . It can be translated that there was a significant difference between the mastery of character values at the pre-test and post-test stage both class with video and class with simple image. Based on that data, it is known that the implementation of video media can increase the mastery of character value to the early childhood students.

3. The difference on the average score of character value mastery for students who apply the video and the simple images using independent test

\begin{tabular}{ccccccc}
\hline Variable & Media & N & Mean & SD & $\begin{array}{c}\text { Standard } \\
\text { Error (SE) }\end{array}$ & $\begin{array}{c}\text { Sig. (2- } \\
\text { tailed) }\end{array}$ \\
\hline Character & Video & 17 & 3.21 & 3.175 & 0.887 & \\
& & & & & & 0.718 \\
& Images & 17 & 2.87 & 2.156 & 0.546 & \\
\hline
\end{tabular}

From the table above, it is illustrated that the average values of student's character mastery which given a treatment with video media is higher than image media, around 3.21 with significance level is 0,718 which means higher than 0.05 . This study results showed that it is found the significant distinction of the average values of the initial knowledge in each category. To examine the effectivity of instructional video implementation, it was then conducted an independent test resulted 0.718 (higher than 0.05). The application of instructional video is more possible to master the character values that only implement the simple image media. It is because by watching the video, the early childhood students can imitate the number of activity and attitude performed on the video. Smaldino (2008) defined instructional video as a media which is enable the images and sound united to show visually through television and the other projection media. The implementation of instructional video has a great influence on the student learning outcome. The result of field test indicated that the application of educational video media and learning strategy affects significantly toward the mastery of character values to the early childhood students.

\section{Conclusions}

Based on the results and the discussion of this research, it can be concluded that, 1) the grade average of students who were given treatment through video had the higher mastery of character values compared to those who were treated only with the simple images, 2) at the pre-test and post-test, students with uncomplicated pictures had the understanding of character values around -2.922 (showed that the score before the treatment were lesser than after it with standard deviation about 2.173. On the contrary, at 
the examination with video, it is obtained the average score around -3.208 with standard deviation 3.172 and alfa around $0.001,3$ ) The influencing actorsof character-based video effectiveness is the implementation of learning strategies, such as discussion method and story-telling by the teachers to build up the mastery of character values to the early childhood students. Regarding to this, it is suggested that the teachers should apply this character-based video media in the process of teaching and learning to improve the understanding of character values of early childhood students.

\section{Acknowledgement}

The researchers would like to express the gratitude to the Head of Universitas Negeri Padang as the research sponsor and also Yayasan Adzkia II as the location of this study about influencing factors of the video implementation to early childhood students.

\section{References}

Hidayati, A., Amsal, M.F., \& Amilia, W. (2018). Development of classroom design model into character education in elementary. In I. Ifdil, \& Z. Ardi (Eds.), Education, Social Sciences and Technology Application in Digital Era (pp. 935 - 938). Padang: Fakultas Ilmu Pendidikan. https://doi.org/10.29210/20181135

Hidayati, A., Amsal, M.F., \& Amilia, W. (2018). Need analysis of media video development for character education at early childhood education in Padang. Advances in Social Science, Education and Humanities Research. doi:10.2991/icece-17.2018.26

Koesoema A, Doni. 2007. Pendidikan Karakter, Strategi Mendidik Anak di Zaman Global. Jakarta: PT. Gramedia Widiasarana Indonesia (Grasindo)

Liang, H., Chang, J., Kazmi, I. K., Zhang, J. J., \& Jiao, P. (2015, September). Puppet Narrator: utilizing motion sensing technology in storytelling for young children. In Games and virtual worlds for serious applications (VS-Games), 2015 7th International Conference on (pp. 1-8). IEEE.

Smaldino, Sharon E., Lowther, Deborah L., Russel, James D. (2008). Instructional Technology and Media for Learning (Nineth Edition). NJ: Pearson Education Inc.

Wang, J, et al (2015). Character in Childhood and Early Adolescence: Models and Measurement. Journal of Moral Education. 44-2, 165-197. 